\title{
Serum Neutralizing Activity against B.1.1.7, B.1.351, and P.1 SARS-CoV-2 Variants of Concern in Hospitalized COVID-19 Patients
}

\author{
Claudia Maria Trombetta ${ }^{1, *(D)}$, Serena Marchi ${ }^{1}\left(\mathbb{D}\right.$, Simonetta Viviani ${ }^{1}$ (D), Alessandro Manenti ${ }^{2}$ (D), \\ Linda Benincasa ${ }^{3}$, Antonella Ruello ${ }^{4}$, Emilio Bombardieri ${ }^{4}$, Ilaria Vicenti ${ }^{5}\left(\mathbb{D}\right.$, Maurizio Zazzi ${ }^{5}$ \\ and Emanuele Montomoli 1,2,3 (D)
}

Citation: Trombetta, C.M.; Marchi, S.; Viviani, S.; Manenti, A.; Benincasa, L.; Ruello, A.; Bombardieri, E.; Vicenti, I.; Zazzi, M.; Montomoli, E. Serum

Neutralizing Activity against B.1.1.7, B.1.351, and P.1 SARS-CoV-2 Variants of Concern in Hospitalized COVID-19 Patients. Viruses 2021, 13, 1347. https://doi.org/10.3390/v13071347

Academic Editors:

Luis Martinez-Sobrido and

Fernando Almazan Toral

Received: 6 May 2021

Accepted: 8 July 2021

Published: 12 July 2021

Publisher's Note: MDPI stays neutral with regard to jurisdictional claims in published maps and institutional affiliations.

Copyright: (c) 2021 by the authors. Licensee MDPI, Basel, Switzerland. This article is an open access article distributed under the terms and conditions of the Creative Commons Attribution (CC BY) license (https:/ / creativecommons.org/licenses/by/ $4.0 /)$.
1 Department of Molecular and Developmental Medicine, University of Siena, 53100 Siena, Italy; serena.marchi2@unisi.it (S.M.); simonetta.viviani@unisi.it (S.V.); emanuele.montomoli@unisi.it (E.M.)

2 VisMederi srl, Strada del Petriccio e Belriguardo 35, 53100 Siena, Italy; alessandro.manenti@vismederi.com

3 VisMederi Research srl, Strada del Petriccio e Belriguardo 35, 53100 Siena, Italy; linda.benincasa@vismederiresearch.com

4 Humanitas Gavazzeni, Via Mauro Gavazzeni 21, 24125 Bergamo, Italy; antonella.ruello@gavazzeni.it (A.R.); emilio.bombardieri@gavazzeni.it (E.B.)

5 Department of Medical Biotechnologies, University of Siena, 53100 Siena, Italy; ilariavicenti@gmail.com (I.V.); maurizio.zazzi@gmail.com (M.Z.)

* Correspondence: trombetta@unisi.it

\begin{abstract}
The recent spreading of new SARS-CoV-2 variants, carrying several mutations in the spike protein, could impact immune protection elicited by natural infection or conferred by vaccination. In this study, we evaluated the neutralizing activity against the viral variants that emerged in the United Kingdom (B.1.1.7), Brazil (P.1), and South Africa (B.1.351) in human serum samples from hospitalized patients infected by SARS-CoV-2 during the first pandemic wave in Italy in 2020 . Of the patients studied, $59.5 \%$ showed a decrease ( $\geq 2$ fold) in neutralizing antibody titer against B.1.1.7, $83.3 \%$ against P.1, and $90.5 \%$ against B.1.351 with respect to the original strain. The reduction in antibody titers against all analyzed variants, and in particular P.1 and B.1.351, suggests that previous symptomatic infection might be not fully protective against exposure to SARS-CoV-2 variants carrying a set of relevant spike mutations.
\end{abstract}

Keywords: neutralizing activity; SARS-CoV-2; variants of concern

\section{Introduction}

One year ago, the Director-General of the World Health Organization declared the first pandemic caused by a coronavirus named severe acute respiratory syndrome coronavirus 2 (SARS-CoV-2) [1]. Neutralizing antibodies, targeting the viral spike (S) protein and its receptor-binding domain (RBD), are considered a surrogate of protection against COVID19 [2], the disease caused by SARS-CoV-2, although no formal correlates of protection have been established so far. In fact, available COVID-19 vaccines that have shown high efficacy are developed with the concept that the $S$ protein is the immunodominant antigen. These vaccines are designed based on the Wuhan strain, the original strain that since January 2020 has been at the origin of the worldwide pandemic.

In the last months, different variants of concern (VOCs) [3] of SARS-CoV-2 emerged around the world, initially as occasional isolates; however, in some settings, the most efficient variants are rapidly replacing the original Wuhan strain.

One new variant emerged in the United Kingdom (UK), affecting people under 60 years of age. Retrospective analyses have dated the first identification as occurring in September 2020 in South East England [4,5]. This variant, called B.1.1.7, spread in several countries around the world (i.e., Italy, Denmark, the United States, the Netherlands, Australia, Iceland), and it has been associated with 50\% increased transmission [6] 
and increased risk of death [4,7-9]. Seventeen mutations/deletions in the viral genome characterize the B.1.1.7, including eight in the S protein $(\Delta 69-70, \Delta Y 144, N 501 Y$, A570D, $\mathrm{P} 681 \mathrm{H}, \mathrm{T} 716 \mathrm{I}, \mathrm{S} 982 \mathrm{~A}, \mathrm{D} 118 \mathrm{H})[5,8]$. Three mutations are of biological significance, namely $\triangle 69-70, N 501 Y$, and P681H. The first one is related to an increased viral infectivity and a potential impact on $\mathrm{PCR}$ assays targeting the $\mathrm{S}$ gene $[4,8,10]$; however, this mutation is not restricted to this variant [10]. The N501Y is a mutation in the RBD resulting in an increased binding affinity to its cellular ACE-2 receptor $[7,8,11]$. The last one, $\mathrm{P} 681 \mathrm{H}$, is supposed to be related to an improved transmissibility of the virus [12].

Two new variants emerged in Brazil, both originating from the B.1.1.28 clade [13]. The first variant (named B.1.1.28.2), detected in October 2020, was characterized by the E484K mutation in the $S$ protein, related to a possible escape from neutralizing antibodies [14]. The second variant (named B.1.1.28.1) was reported by the National Institute of Infectious Diseases in Japan after sampling of Brazilian travelers to Japan. Since this variant presents other substantial mutations such as H655Y, L18F, D138Y, and N501Y, in addition to the E484K $[7,13,15]$, it was classified as a "variant of concern" [16]. Notably, the E484K mutation is in common with the B.1.351 variant first identified in the Republic of South Africa but not with B.1.1.7 [13]. The P.1 and B.1.351 variants share common mutations in the $S$ protein, increasing the possibility of evasion of the humoral response and enhanced transmissibility $[13,17]$.

As of 2 March 2021, B.1.1.7 accounts for 54.0\% of Italian cases nationwide, ranging from 0 to $93.3 \%$ between regions, and is becoming the most widely present variant in the country. The P.1 variant is less prevalent for now, accounting for $4.3 \%$ of all new local COVID-19 cases, while B.1.351 is involved in just $0.4 \%$ of new cases [18]. Recently, a new VOC emerged, the SARS-CoV-2 B.1.617.2, also named Delta, first detected in India and now dominant in the UK $[19,20]$. The new variant has overtaken B.1.1.7 in the UK, and it is estimated that it will represent $90 \%$ of all viruses circulating in Europe by the end of August $[19,21]$. Additionally, it seems to be characterized by a higher risk of hospital admission and increased transmissibility $[19,20,22]$. Here we assess the neutralization activity against B.1.1.7, P.1, and B.1.351 variants in a panel of human serum samples from hospitalized infected COVID-19 patients, previously tested by 2019-nCov/Italy-INMI1, clade V strain (Wuhan strain).

\section{Materials and Methods}

\subsection{Study Population}

Sera of 42 COVID-19 patients (35 recovered and 7 with fatal outcome), hospitalized at Humanitas Gavazzeni (Bergamo, Italy) during the first epidemic wave that occurred in Italy between March and May 2020, were included in the present study. Subject characteristics and study procedures were described in detail elsewhere (approval number 17373-Ethics Committee of the University of Siena; approval number 17/20-Ethics Committee of Humanitas Gavazzeni) [23].

For the purpose of the present study, sera available for each patient at three time points were selected: the hospital admission sample (baseline), the sample showing the highest neutralizing antibody titer against 2019-nCov/Italy-INMI1 strain (hereafter referred to as wild-type (wt) strain) found in the previous study [23] and defined as "peak", and the last sample available during hospital stay. For 22 patients, the "peak" sample was the last sample available during the hospital stay. Samples of deceased/recovered patients were pulled together for the purpose of this study, as in the original study no difference was found between the 2 groups in terms of neutralizing antibody titers with respect to the wt strain.

\subsection{Cell Culture and Viral Growth}

VERO E6 cells (ATCC-CRL 1586) were cultured in Dulbecco's Modified Eagle's Medium (DMEM), High Glucose (Euroclone, Pero, Italy), supplemented with $2 \mathrm{mM} \mathrm{L-}$ glutamine (Lonza, Milano, Italy), 100 units/mL penicillin-streptomycin mixture (Lonza, 
Milano, Italy) and $10 \%$ fetal bovine serum (FBS) (Euroclone, Pero, Italy), in a $37^{\circ} \mathrm{C}$ and $5 \%$ $\mathrm{CO}_{2}$ humidified incubator.

Adherent subconfluent cell monolayers of VERO E6 were prepared in growth medium (DMEM High Glucose containing 2\% FBS, 2 mM L-glutamine, 100 units $/ \mathrm{mL}$ penicillinstreptomycin) in $175 \mathrm{~cm}^{2}$ flasks or 96-well plates for propagation or titration and neutralization tests of SARS-CoV-2, respectively.

Cells were seeded in a $175 \mathrm{~cm}^{2}$ flask at a density of $1 \times 10^{6}$ cells $/ \mathrm{mL}$. After $18-20 \mathrm{~h}$, the subconfluent cell monolayer was washed twice with sterile Dulbecco's phosphate-buffered saline (DPBS). After the DPBS was removed, cells were infected with $3.5 \mathrm{~mL}$ of DMEM $2 \%$ FBS containing the SARS-CoV-2 virus at a multiplicity of infection (MOI) of 0.01 . After $1 \mathrm{~h}$ of incubation at $37^{\circ} \mathrm{C}$ in a humidified atmosphere with $5 \% \mathrm{CO}_{2}, 50 \mathrm{~mL}$ of DMEM containing $2 \%$ FBS was added. The flasks were observed daily, and the virus was harvested when $80-90 \%$ of the cells manifested cytopathic effect (CPE). The culture medium was centrifuged at $+4{ }^{\circ} \mathrm{C}$ and $469 \times g$ for 8 min, aliquoted, and stored at $-80^{\circ} \mathrm{C}$.

\subsection{SARS-CoV-2 Viruses}

The SARS-CoV-2 (nCoV strain 2019-nCov/Italy-INMI1 strain) wt virus was purchased from the European Virus Archive goes Global (EVAg, Spallanzani Institute, Rome). Notably, the used strain did not carry the S protein amino acid change D614G.

The B.1.1.7 named England/MIG457/2020 and the B.1.351 variant named hCoV19/Netherlands/NoordHolland_10159/2021, next strain clade 20H, wt viruses were purchased from EVAg.

The P.1 variant (next strain 20J/501Y.V3) (lineage B.1.1.28.1) was kindly provided by the University of Siena, Department of Medical Biotechnology.

\subsection{Virus Neutralization Assay}

The virus neutralization (VN) assay was performed as previously reported [24]. Briefly, after heat-inactivation for $30 \mathrm{~min}$ at $56^{\circ} \mathrm{C}$, serum samples, starting from 1:10 dilution, were mixed with an equal volume of SARS-CoV-2 (B.1.1.7, P.1, and B.1.351) viral solution containing 100 tissue culture infective dose $50 \%$ (TCID50). After $1 \mathrm{~h}$ of incubation at room temperature, $100 \mu \mathrm{L}$ of virus-serum mixture was added to a 96-well plate containing an $80 \%$ confluent Vero E6 cell monolayer. Plates were incubated for 4 days at $37^{\circ} \mathrm{C}$ and $5 \% \mathrm{CO}_{2}$ in humidified atmosphere and then checked for presence/absence of $\mathrm{CPE}$ by an inverted optical microscope. A CPE higher than $50 \%$ indicated infection. The VN titer was expressed as the reciprocal of the highest serum dilution showing protection from viral infection and CPE.

\subsection{Statistical Analysis}

All statistical analyses were performed using GraphPad Prism version 6.01 for Windows (GraphPad Software, San Diego, CA, USA [25]. For each variant, the mean fold decrease in antibody levels with respect to the $w t$ strain was calculated along with its standard deviation (SD). Antibody levels were expressed as log and statistically evaluated with respect to the wt strain using a paired $t$-tests. Statistical significance was set at $p<0.05$, two-tailed.

\section{Results}

Neutralizing antibody titers of each patient by time point and variant are shown in Figure 1 with statistically significant titer decrease for all three variants at any time point at hospital admission (baseline); 10 patients $(23.8 \%)$ were negative for neutralizing antibodies against the wt strain as well as for all the variants. In total, 16 patients $(38.1 \%)$ were negative for B.1.1.7, 20 (47.6\%) were negative for P.1, and 30 (71.4\%) were negative for B.1.351 at baseline. Twenty-three (54.8\%) and $30(71.4 \%)$ patients showed a $\geq 2$-fold decrease in neutralizing antibody titer when tested against B.1.1.7 and P.1, respectively (Table 1a,b). Thirty-two patients $(76.2 \%)$ showed a $\geq 2$-fold decrease in neutralizing antibody titer 
against B.1.351 (Table 1c). A significant decrease in neutralizing antibody titers against all three variants $(p<0.0001)$ was observed with respect to the wt strain.
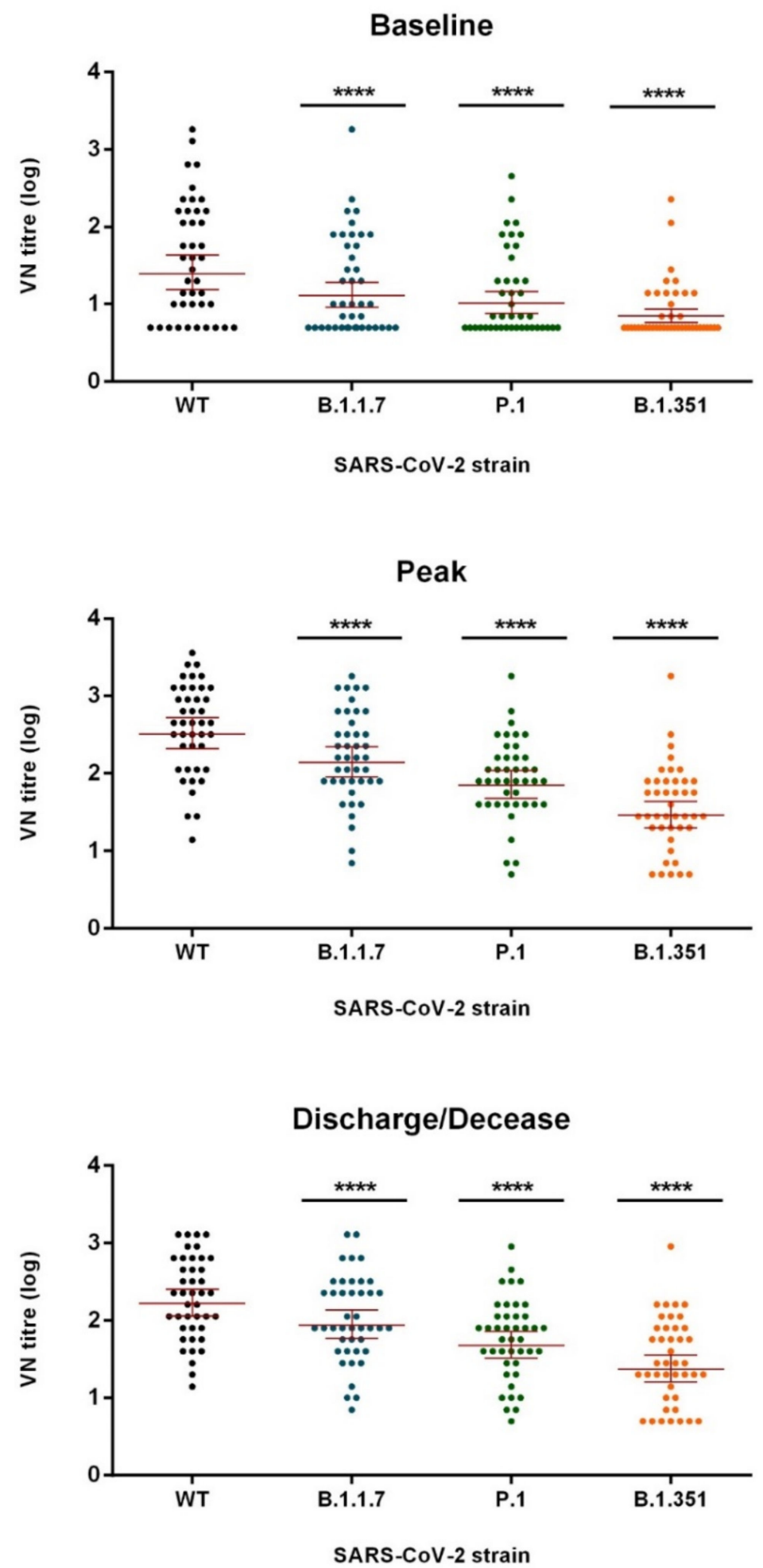

Figure 1. SARS-CoV-2 virus-neutralization (VN) titers with geometric mean and 95\% confidence intervals, by time point and strain. For each variant, $\mathrm{VN}$ titers were compared with respect to the wt strain using a paired $t$-test $\left.{ }^{* * * *} p \leq 0.0001\right)$. 
Table 1. Fold decrease in neutralizing antibody titers of B.1.1.7 (a), P.1 (b) and B.1.351 (c) variants with respect to the wt strain by time point (baseline, peak, and discharge/decease).

\begin{tabular}{|c|c|c|c|c|c|c|}
\hline \multicolumn{7}{|c|}{ (a) B.1.1.7 Variant } \\
\hline & \multicolumn{2}{|c|}{ Baseline } & \multicolumn{2}{|c|}{ Peak } & \multicolumn{2}{|c|}{ Discharge/Decease } \\
\hline & $\mathbf{N}$ & $\%$ & $\mathbf{N}$ & $\%$ & $\mathbf{N}$ & $\%$ \\
\hline - & 19 & $45.2 \%$ & 16 & $38.1 \%$ & 17 & $40.5 \%$ \\
\hline 2-fold & 12 & $28.6 \%$ & 14 & $33.3 \%$ & 16 & $38.1 \%$ \\
\hline 4-fold & 7 & $16.7 \%$ & 8 & $19.0 \%$ & 9 & $21.4 \%$ \\
\hline$>4$-fold & 4 & $9.5 \%$ & 4 & $9.5 \%$ & 0 & $0.0 \%$ \\
\hline Total & 42 & $100 \%$ & 42 & $100 \%$ & 42 & $100 \%$ \\
\hline Mean fold & 3.0 & & 3.5 & & 2.3 & \\
\hline (SD) & $(3.1)$ & & $(5.0)$ & & $(1.4)$ & \\
\hline \multicolumn{7}{|c|}{ (b) P.1 Variant } \\
\hline & \multicolumn{2}{|c|}{ Baseline } & \multicolumn{2}{|c|}{ Peak } & \multicolumn{2}{|c|}{ Discharge/Decease } \\
\hline & $\mathbf{N}$ & $\%$ & $\mathbf{N}$ & $\%$ & $\mathbf{N}$ & $\%$ \\
\hline- & 12 & $28.6 \%$ & 5 & $11.9 \%$ & 7 & $16.7 \%$ \\
\hline 2-fold & 15 & $35.7 \%$ & 10 & $23.8 \%$ & 14 & $33.3 \%$ \\
\hline 4-fold & 6 & $14.3 \%$ & 12 & $28.6 \%$ & 14 & $33.3 \%$ \\
\hline$>4$-fold & 9 & $21.4 \%$ & 15 & $35.7 \%$ & 7 & $16.7 \%$ \\
\hline Total & 42 & $100 \%$ & 42 & $100 \%$ & 42 & $100 \%$ \\
\hline Mean fold & 4.3 & & 6.0 & & 4.4 & \\
\hline$(\mathrm{SD})$ & $(4.5)$ & & $(4.3)$ & & $(3.4)$ & \\
\hline \multicolumn{7}{|c|}{ (c) B.1.351 Variant } \\
\hline & \multicolumn{2}{|c|}{ Baseline } & \multicolumn{2}{|c|}{ Peak } & \multicolumn{2}{|c|}{ Discharge/Decease } \\
\hline & $\mathbf{N}$ & $\%$ & $\mathbf{N}$ & $\%$ & $\mathbf{N}$ & $\%$ \\
\hline - & 10 & $23.8 \%$ & 4 & $9.5 \%$ & 4 & $9.5 \%$ \\
\hline 2-fold & 10 & $23.8 \%$ & 5 & $11.9 \%$ & 9 & $21.4 \%$ \\
\hline 4-fold & 2 & $4.8 \%$ & 5 & $11.9 \%$ & 6 & $14.3 \%$ \\
\hline$>4$-fold & 20 & $47.6 \%$ & 28 & $66.7 \%$ & 23 & $54.8 \%$ \\
\hline Total & 42 & $100 \%$ & 42 & $100 \%$ & 42 & $100 \%$ \\
\hline Mean fold & 10.2 & & 18.5 & & 11.0 & \\
\hline (SD) & (14.9) & & (18.9) & & (12.3) & \\
\hline
\end{tabular}

- means a decrease less than 2-fold; SD: standard deviation.

Twenty-six samples $(61.9 \%)$ with peak neutralizing titers for the wt strain had a $\geq 2$-fold decrease in neutralizing antibody titer against B.1.1.7, with a mean decrease of 3.5-fold (SD 5.0). In particular, 14 (33.3\%) showed a 2-fold decrease, 8 (19.0\%) showed a 4 -fold decrease, and $4(9.5 \%)$ showed a $>4$-fold decrease (Table 1a). When tested for P.1, 37 (88.1\%) had a $\geq 2$-fold decrease with a mean decrease of 6.0 -fold (SD 4.3). Ten $(23.8 \%)$ showed a 2 -fold decrease, $12(28.6 \%)$ showed a 4 -fold decrease, and $15(35.7 \%)$ showed a $>4$-fold decrease (Table $1 b)$. When tested for B.1.351, $38(90.5 \%)$ showed a $\geq 2$-fold decrease with a mean decrease of 18.5-fold (SD 18.9); 5 (11.9\%) showed a 2-fold decrease, $5(11.9 \%)$ showed a 4 -fold decrease, and $28(66.7 \%)$ showed a $\geq 4$-fold decrease (Table 1c). The decrease in neutralizing antibody titer with respect to the wt strain was significant for all three variants $(p<0.0001)$.

At discharge/decease, all patients showed neutralizing antibody against the wt strain, although a decline in titer was observed as deeply described elsewhere [23]. When tested against B.1.1.7, one patient (2.4\%) was found negative. A $\geq 2$-fold decrease was observed in $25(59.5 \%)$ patients: $16(38.1 \%)$ and $9(21.4 \%)$ showed a 2-fold and 4-fold decrease, respectively (mean decrease 2.3-fold (SD 1.4)) (Table 1a). Three patients (7.1\%) were found negative when tested against P.1, and a $\geq 2$-fold decrease was observed in 35 (83.3\%) patients. In particular, $14(33.3 \%)$ showed a 2 -fold decrease, $14(33.3 \%)$ showed a 4 -fold decrease, and $7(16.7 \%)$ showed a $>4$-fold decrease, with a mean decrease of 4.4 -fold (SD 3.4) (Table 1b).

Nine patients (21.4\%) were found negative when tested against B.1.351, and a $\geq 2$-fold decrease was observed in $38(90.5 \%)$ patients. In particular, $9(21.4 \%)$ showed a 2 -fold decrease, 6 (14.3\%) showed a 4-fold decrease, and 23 (54.8\%) showed a $>4$-fold decrease, 
with a mean decrease of 11.0-fold (SD 12.3). The decrease in neutralizing antibody titer was statistically significant for all three variants $(p<0.0001)$ with respect to the wt strain.

\section{Discussion}

Recently, different variants of SARS-CoV-2 with mutations in the S protein have emerged, raising concerns about the protection elicited by natural infection or conferred by vaccination.

In this study, we evaluated the neutralizing activity against B.1.1.7, P.1, and B.1.351 VOCs in a panel of human serum samples from hospitalized patients infected by SARSCoV-2 between March and May 2020 during the first wave of the pandemic in Italy [23].

Although we assessed the neutralizing activity at three time points for each patient, namely hospital admission (baseline), neutralizing antibody titer peak, and the last time point available (at discharge or decease), here we mainly discuss the last one since it may represent the "antibody baggage".

In our study, $59.5 \%$ of the patients had a decrease ( $\geq 2$-fold) in neutralizing antibody titer against B.1.1.7, and 21.4\% showed a 4-fold decrease, as shown in a similar study [26]. On the contrary, other studies have reported that samples from convalescent or hospitalized patients are able to neutralize the B.1.1.7 variant, either maintaining similar levels of neutralizing activity or exhibiting a modest decrease compared to the original antibody titer [27-29]. We can hypothesize that the decrease in neutralizing antibody titer found in our study may be ascribed to the wt virus used, lacking D614G mutation. In general, the modest change in the potency of neutralization against this variant could be related to the N501Y mutation that, even though related to an increased binding to the ACE-2 receptor, does not appear to have a significant implication for neutralizing activity [28].

Regarding the P.1 variant, $83.3 \%$ of the patients involved in the study showed significantly reduced neutralizing activity ( $\mathrm{a} \geq 2$-fold decrease), and $16.7 \%$ had a decrease higher than 4-fold, almost twice that reported for B.1.1.7. The reduction in neutralizing activity was even higher against the B.1.351 variant, with $90.5 \%$ of patients showing a fold decrease of $\geq 2$ with a mean decrease almost 3 times higher than that against the P.1 variant. These findings are consistent with other studies $[27,28,30,31]$ in which a reduced neutralizing potency of antibodies against these variants has been reported, although convalescent and vaccinated sera seem to better neutralize P.1 than B.1.351. The reduced neutralization could be ascribed to the E484K mutation shared between P.1 and B.1.351 and related to a possible escape from neutralizing antibodies. Considering that some mutations of P.1 are in common with B.1.351, such as the E484K mutation, it is very likely that a similar or higher reduction in neutralizing antibodies may be caused by variants carrying the same mutation. The immunoevasion could lead to reinfection of subjects who recovered from a previous infection [16] and could reduce the protection induced by vaccination and/or natural infection [27]. However, recent studies have proven that boosting pre-existing immunity against SARS-CoV-2 with one dose of mRNA vaccine induces a strong neutralizing response even against divergent variants (i.e., B.1.351) [8,32]. In Italy, subjects naturally infected by SARS-CoV-2 receive just one dose of vaccine from 3 to 6 months after infection [33]. In addition, a recent study [34] reported that neutralizing antibodies after natural infection by SARS-CoV-2 can last for at least 9 months.

Notably, one serum sample was not able to neutralize the B.1.1.7 variant, three were not able to neutralize the P.1 variant, and nine were not able to neutralize the B.1.351 variant, suggesting that symptomatic subjects previously infected by SARS-CoV-2 wt virus might not be fully protected against the emerging variants.

A key strength of the study is that the neutralizing activity has been assessed using authentic live SARS-CoV-2 viruses and not surrogate VN assay.

This study has some limitations. First, the cohort only included hospitalized patients, which may not be representative of the general population. The lack of follow-up samples after discharge does not allow the assessment of the full breadth of cross-neutralization potential that can be reached following more extended affinity maturation. 
Overall, our findings provide evidence of a remarkable lower neutralization capacity of SARS-CoV-2 antibodies acquired during the first wave of the pandemic against the B.1.351 variant, and to a lesser extent against P.1 and B.1.1.7. This might suggest the possibility of reinfection or that previously infected individuals may be partially protected against current and new emerging variants with relevant mutations. However, the immune response induced by natural infection may protect from severe disease [35]. The emergence of the Delta VOC is also raising concern; however, so far, it appears that vaccines remain effective, especially after two doses [21,22,36]. Our study highlights the importance of evaluating SARS-CoV-2 pre-existing immunity against emerging variants as a tool to foresee the immune escape and the extent of vaccine efficacy.

Author Contributions: C.M.T., conceptualization, funding acquisition, investigation, project administration, writing - original draft preparation; S.M., investigation, data curation, formal analysis, writing—review and editing; S.V., writing — review and editing; A.M., methodology, writing — review and editing; L.B., methodology, writing-review and editing; A.R., resources, writing-review \& editing; E.B., resources, writing—review \& editing; I.V., resources, methodology, writing — review and editing; M.Z., resources, methodology, writing — review and editing; E.M., methodology, writingreview and editing. All authors have read and agreed to the published version of the manuscript.

Funding: This research received no external funding.

Institutional Review Board Statement: The study was conducted according to the guidelines of the Declaration of Helsinki and approved by the Ethics Committee of the University of Siena (approval number 17373, approval date June 1, 2020) and by the Ethics Committee of Humanitas Gavazzeni (approval number 236 Protocol 670/20, approval date September 22, 2020).

Informed Consent Statement: Patient consent was waived since all serum samples have been fully anonymized before testing.

Data Availability Statement: Data is contained within the article.

Acknowledgments: This study was supported by the European Virus Archive goes Global (EVAg) project, which has received funding from the European Union's Horizon 2020 research and innovation programme under grant agreement No. 653316.

Conflicts of Interest: The authors declare no conflict of interest.

\section{References}

1. World Health Organization. WHO Director-General's Opening Remarks at the Media Briefing on COVID-19-11 March 2020. 2020. Available online: https://www.who.int/dg/speeches/detail/who-director-general-s-opening-remarks-at-the-mediabriefing-on-covid-19---11-march-2020 (accessed on 4 May 2021).

2. Algaissi, A.; Alfaleh, M.A.; Hala, S.; Abujamel, T.S.; Alamri, S.S.; Almahboub, S.A.; Alluhaybi, K.A.; Hobani, H.I.; Alsulaiman, R.M.; AlHarbi, R.H.; et al. SARS-CoV-2 S1 and N-based serological assays reveal rapid seroconversion and induction of specific antibody response in COVID-19 patients. Sci. Rep. 2020, 10, 16561. [CrossRef]

3. CDC. SARS-CoV-2 Variant Classifications and Definitions. 2021. Available online: https://www.cdc.gov/coronavirus/2019 -ncov/cases-updates/variant-surveillance/variant-info.html\#Concern (accessed on 6 April 2021).

4. WHO. SARS-CoV-2 Variant-United Kingdom of Great Britain and Northern Ireland. 2020. Available online: https://www.who. $\mathrm{int} / \mathrm{csr} /$ don/21-december-2020-sars-cov2-variant-united-kingdom/en/ (accessed on 6 April 2021).

5. Burki, T. Understanding variants of SARS-CoV-2. Lancet 2021, 397, 462. [CrossRef]

6. Davies, N.G.; Abbott, S.; Barnard, R.C.; Jarvis, C.I.; Kucharski, A.J.; Munday, J.D.; Pearson, C.A.B.; Russell, T.W.; Tully, D.C.; Washburne, A.D.; et al. Estimated transmissibility and impact of SARS-CoV-2 lineage B.1.1.7 in England. Science 2021, 372, eabg3055. [CrossRef]

7. CDC. Science Brief: Emerging SARS-CoV-2 Variants. 2021. Available online: https://www.cdc.gov/coronavirus / 2019-ncov/ science/science-briefs/scientific-brief-emerging-variants.html (accessed on 6 April 2021).

8. Wu, K.; Werner, A.P.; Moliva, J.I.; Koch, M.; Choi, A.; Stewart-Jones, G.B.E.; Bennett, H.; Boyoglu-Barnum, S.; Shi, W.; Graham, B.S.; et al. mRNA-1273 vaccine induces neutralizing antibodies against spike mutants from global SARS-CoV-2 variants. bioRxiv 2021. [CrossRef]

9. Davies, N.G.; Jarvis, C.I.; CMMID COVID-19 Working Group; Edmunds, J.W.; Jewell, N.P.; Diaz-Ordaz, K.; Keogh, R.H. Increased mortality in community-tested cases of SARS-CoV-2 lineage B.1.1.7. Nature 2021, 593, 270-274. [CrossRef] [PubMed] 
10. eCDC. Rapid Increase of a SARS-CoV-2 Variant with Multiple Spike Protein Mutations Observed in the United Kingdom. 2020, pp. 1-13. Available online: https:/ / www.ecdc.europa.eu/sites/default/files/documents/SARS-CoV-2-variant-multiple-spike-proteinmutations-United-Kingdom.pdf (accessed on 12 July 2021).

11. Muik, A.; Wallisch, A.K.; Sanger, B.; Swanson, K.A.; Muhl, J.; Chen, W.; Cai, H.; Maurus, D.; Sarkar, R.; Tureci, O.; et al. Neutralization of SARS-CoV-2 lineage B.1.1.7 pseudovirus by BNT162b2 vaccine-elicited human sera. Science 2021, 371, $1152-1153$. [CrossRef]

12. Zuckerman, N.S.; Fleishon, S.; Bucris, E.; Bar-Ilan, D.; Linial, M.; Bar-Or, I.; Mor, O. A unique SARS-CoV-2 spike protein P681H strain detected in Israel. medRxiv 2021. [CrossRef]

13. Toovey, O.T.R.; Harvey, K.N.; Bird, P.W.; Tang, J.W.W. Introduction of Brazilian SARS-CoV-2 484K.V2 related variants into the UK. J. Infect. 2021. [CrossRef] [PubMed]

14. Nonaka, C.K.V.; Franco, M.M.; Graf, T.; de Lorenzo Barcia, C.A.; de Avila Mendonca, R.N.; de Sousa, K.A.F.; Neiva, L.M.C.; Fosenca, V.; Mendes, A.V.A.; de Aguiar, R.S. Genomic Evidence of SARS-CoV-2 Reinfection Involving E484K Spike Mutation, Brazil. Emerg. Infect. Dis. 2021, 27, 1522-1524. [CrossRef]

15. Sabino, E.C.; Buss, L.F.; Carvalho, M.P.S.; Prete, C.A., Jr.; Crispim, M.A.E.; Fraiji, N.A.; Pereira, R.H.M.; Parag, K.V.; da Silva Peixoto, P.; Kraemer, M.U.G.; et al. Resurgence of COVID-19 in Manaus, Brazil, despite high seroprevalence. Lancet 2021, 397, 452-455. [CrossRef]

16. Naveca, F.; da Costa, C.; Nascimento, V.; Souza, V.; Corado, A.; Nascimento, F.; Costa, A.; Duarte, D.; Silva, G.; Mejía, M.; et al. SARS-CoV-2 Reinfection by the New Variant of Concern (VOC) P.1 in Amazonas, Brazil. 2021. Available online: https:/ / virological.org/t/sars-cov-2-reinfection-by-the-new-variant-of-concern-voc-p-1-in-amazonas-brazil/596 (accessed on 12 July 2021).

17. Fontanet, A.; Autran, B.; Lina, B.; Kieny, M.P.; Karim, S.S.A.; Sridhar, D. SARS-CoV-2 variants and ending the COVID-19 pandemic. Lancet 2021, 397, 952-954. [CrossRef]

18. ISS. CS N $N^{\circ} 14 / 2021$ - In Italia il 54\% Delle Infezioni Dovute a 'Variante Inglese', il 4,3\% a Quella ‘Brasiliana' e lo 0,4\% a Quella 'Sudafricana'. 2021. Available online: https://www.iss.it/comunicati-stampa/-/asset_publisher/fjTKmjJgSgdK/content/ id/5647546?_com_liferay_asset_publisher_web_portlet_AssetPublisherPortlet_INSTANCE_fjTKmjJgSgdK_redirect=https\% 3A\%2F\%2Fwww.iss.it\%2Fcomunicatistampa\%3Fp_p_id\%3Dcom_liferay_asset_publisher_web_portlet_AssetPublisherPortlet_ INSTANCE_fjTKmjJgSgdK\%26p_p_lifecycle\%3D0\%26p_p_state\%3Dnormal\%26p_p_mode\%3Dview\%26_com_liferay_asset_ publisher_web_portlet_AssetPublisherPortlet_INSTANCE_fjTKmjJgSgdK_cur\%3D0\%26p_r_p_resetCur\%3Dfalse\%26_com_ liferay_asset_publisher_web_portlet_AssetPublisherPortlet_INSTANCE_fjTKmjJgSgdK_assetEntryId\%3D5647546 (accessed on 6 April 2021).

19. Torjesen, I. Covid-19: Delta variant is now UK's most dominant strain and spreading through schools. BMJ 2021, $373, \mathrm{n} 1445$. [CrossRef]

20. Wall, E.C.; Wu, M.; Harvey, R.; Kelly, G.; Warchal, S.; Sawyer, C.; Bauer, D.L. Neutralising antibody activity against SARS-CoV-2 VOCs B.1.617.2 and B.1.351 by BNT162b2 vaccination. Lancet 2021, 397, 2331-2332. [CrossRef]

21. eCDC. ECDC Statement on the SARS-CoV-2 Delta Variant in the EU/EEA. Available online: https://www.ecdc.europa.eu/en/ news-events / ecdc-statement-sars-cov-2-delta-variant-eueea (accessed on 24 June 2021).

22. Bernal, J.L.; Andrews, N.; Gower, C.; Gallagher, E.; Simmons, R.; Thelwall, S.; Ramsay, M. Effectiveness of COVID-19 vaccines against the B.1.617.2 variant. medRxiv 2021. [CrossRef]

23. Marchi, S.; Simonetta, V.; Remarque, E.; Ruello, A.; Bombardieri, E.; Bollati, V.; Trombetta, C. Characterization of antibody response in asymptomatic and symptomatic SARS-CoV-2 infection. PLoS ONE 2021. [CrossRef]

24. Manenti, A.; Maggetti, M.; Casa, E.; Martinuzzi, D.; Torelli, A.; Trombetta, C.M.; Marchi, S.; Montomoli, E. Evaluation of SARS-CoV-2 neutralizing antibodies using a CPE-based colorimetric live virus micro-neutralization assay in human serum samples. J. Med. Virol. 2020, 92, 2096-2104. [CrossRef] [PubMed]

25. GraphPad Software. Available online: http://www.graphpad.com (accessed on 17 June 2021).

26. Supasa, P.; Zhou, D.; Dejnirattisai, W.; Liu, C.; Mentzer, A.J.; Ginn, H.M.; Screaton, G.R. Reduced neutralization of SARS-CoV-2 B.1.1.7 variant by convalescent and vaccine sera. Cell 2021, 184, 2201-2211. [CrossRef] [PubMed]

27. Tada, T.; Dcosta, B.M.; Samanovic-Golden, M.; Herati, R.S.; Cornelius, A.; Mulligan, M.J.; Landau, N.R. Neutralization of viruses with European, South African, and United States SARS-CoV-2 variant spike proteins by convalescent sera and BNT162b2 mRNA vaccine-elicited antibodies. bioRxiv 2021. [CrossRef]

28. Wang, P.; Nair, M.S.; Liu, L.; Iketani, S.; Luo, Y.; Guo, Y.; Wang, M.; Yu, J.; Zhang, B.; Kwong, P.D.; et al. Antibody resistance of SARS-CoV-2 variants B.1.351 and B.1.1.7. Nature 2021, 593, 130-135. [CrossRef]

29. Rees-Spear, C.; Muir, L.; Griffith, S.A. The impact of Spike mutations on SARS-CoV-2 neutralization. bioRxiv 2021, 1-26. [CrossRef]

30. Chen, R.E.; Zhang, X.; Case, J.B.; Winkler, E.S.; Liu, Y.; VanBlargan, L.A.; Liu, J.; Errico, J.M.; Xie, X.; Suryadevara, N.; et al. Resistance of SARS-CoV-2 variants to neutralization by monoclonal and serum-derived polyclonal antibodies. Nat. Med. 2021, 27, 717-726. [CrossRef] [PubMed]

31. Stamatatos, L.; Czartoski, J.; Wan, Y.H.; Homad, L.J.; Rubin, V.; Glantz, H.; Neradilek, M.; Seydoux, E.; Jennewein, M.F.; MacCamy, A.J.; et al. mRNA vaccination boosts cross-variant neutralizing antibodies elicited by SARS-CoV-2 infection. Science 2021. [CrossRef] [PubMed] 
32. Ebinger, J.E.; Fert-Bober, J.; Printsev, I.; Wu, M.; Sun, N.; Prostko, J.C.; Frias, E.C.; Stewart, J.L.; van Eyk, J.E.; Braun, J.G.; et al. Antibody responses to the BNT162b2 mRNA vaccine in individuals previously infected with SARS-CoV-2. Nat. Med. 2021. [CrossRef] [PubMed]

33. Ministero Della SALUTE. OGGETTO: Vaccinazione dei Soggetti che Hanno Avuto Un'infezione da SARS-CoV-2. 2021. Available online: http:/ / www.regioni.it/sanita/2021/03/04/ministero-della-salute-circolare-vaccinazione-dei-soggetti-che-hanno-avutouninfezione-da-sars-cov-2-03-03-2021-630251/ (accessed on 1 April 2021).

34. He, Z.Y.; Ren, L.L.; Yang, J.T.; Guo, L.; Feng, L.Z.; Ma, C.; Wang, X.; Leng, Z.W.; Tong, X.L.; Zhou, W.; et al. Seroprevalence and humoral immune durability of anti-SARS-CoV-2 antibodies in Wuhan, China: A longitudinal, population-level, cross-sectional study. Lancet 2021, 397, 1075-1084. [CrossRef]

35. Naveca, F.; da Costa, C.; Nascimento, V.; Souza, V.; Corado, A.; Nascimento, F.; Resende, P.C. Three SARS-CoV-2 reinfection cases by the new Variant of Concern (VOC) P.1/501Y.V3. Res. Sq. 2021, 1-13. [CrossRef]

36. Stowe, J.; Andrews, N.; Gower, C.; Gallagher, E.; Utsi, L.; Simmons, R. Effectiveness of COVID-19 Vaccines against Hospital Admission with the Delta (B.1.617.2) Variant. Available online: https:/ / media.tghn.org/articles/Effectiveness_of_COVID-19 _vaccines_against_hospital_admission_with_the_Delta_B._G6gnnqJ.pdf (accessed on 23 June 2021). 